\title{
ACCRUAL EARNINGS MANAGEMENT, REAL EARNINGS MANAGEMENT AND FIRM PERFORMANCE: A PANEL DATA ANALYSIS
}

\author{
Abraham Lincoln Ayisi ${ }^{1}$, Zhang Wenfang ${ }^{2}$, Joseph Adu-Gyamfi ${ }^{3}$ \\ Agyemang Kwasi Sampene ${ }^{4}$, Ofori Charles ${ }^{5}$
}

\author{
${ }^{1}$ School of Finance and Economics, Jiangsu University, Zhenjiang, 212013, China \\ ${ }^{2}$ School of Finance and Economics, Jiangsu University, Zhenjiang, 212013, China \\ ${ }^{3}$ School of Finance and Economics, Jiangsu University, Zhenjiang, 212013, China \\ ${ }^{4}$ School of Management, Jiangsu University, Zhenjiang, 212013, P.R. China \\ ${ }^{5}$ School of Finance and Economics, Jiangsu University, Zhenjiang, 212013, China
}

Article DOI: $\underline{\text { https://doi.org/10.36713/epra7078 }}$

DOI No: 10.36713/epra7078

\begin{abstract}
This research purposely looks into earnings management and how it relates to firm performance. By attempt of gaining empirical results, we proxy firm performance by return on assets (ROA) and return on equity (ROE) as dependent variables. We respectively model discretionary accruals and abnormal cash flow from operations as independent variables supported by firm size, leverage, and liquidity as control variables. Panel analysis was adopted to test a sample of 14 non-financial listed on the Ghana Stock Exchange from 2008 to 2019. We find that firms use both accrual earnings and real earnings methods to manage earnings. Results further indicate firms employ the efficient concept of earnings management to facilitate positive firm performance. Our analysis shows that companies with future acquisition prospects can use earnings management to boost financial efficiency. Although we find evidence of a positive relationship between EM and firm performance, we encourage authorities and facilitators to implement rules requiring transparent financial information to mitigate misleading results and reduce managers' discretion. Prospective investors must also perform an in-depth review of financial records prior to investing. Finally, our research has added to the body of expertise on earnings management, which positively impacts firm performance.
\end{abstract}

KEYWORDS: Earnings Management, Sales Manipulation, Ghana Stock Exchange, Firm Performance.

\section{INTRODUCTION}

A dominant body of literature on earnings management and the connection with performance of companies have been studied (Khuong et al. 2019; Linck et al. 2013; Jiang et al., 2018; Darmawan et al. 2019; Dakhlallh, 2020; Chairunesia et al., 2020). Events of contradictory and inconclusive results have been met on how earnings management practices influence firm performance. Evidence of significant yet recommendable aspect of the practice of earnings management has been duly noted as informational or efficient technique when a positive link is established with firm performance. For example, Linck et al., (2013) found evidence that financially constraint firms use accrual earnings management to gain strong financial status. Nevertheless, a proportionate number of studies have established a negative relationship between earnings management and firm performance (Mostafa, 2020; Mellado \& Soana (2019) indicating an opportunistic approach to managing income.

The contradiction in the results of extant studies must be duly noted by the fact that the studies are based on developed and emerging economies. Thus, studies 
in developed economies differs from the outcome of research in other settings. Although earnings management practices are still practiced in advanced countries, there have been previous assertions that the level of income management is dominant in emerging economies (Matteo \& Francesco, 2018). The practice's economic implication is intuitively scored as substandard; however, empirical arguments have been raised due to previous studies' contradictory nature signposting that earnings management's practice could positively or negatively impact firms' performance.

Previous researchers divided earnings management into two categories.; thus, accrual earnings management (AEM) and real earnings management (REM) (Healy \& Wahlen, 1999; Roychowdhury, 2006; Schipper, 1989). Accrual earnings management has been known to be widely used until the introduction of the Sarbane Oxy (SOX) Act 2002 which resulted in a significant decrease of the method. Real earnings on the other hand gained recognition and attention of firms. However, both practices are still employed to date, particularly in emerging economies.

Regarding firms in Ghana, the Ghana Stock Exchange has reported the delisting and suspension of firms from the market. Reports indicate the situation is attributed to a plethora of management issues, including performance. The market has experienced wide low and high fluctuations of performance in recent years. Notably, in 2015 to 2017, the Ghana Stock Exchange Composite Index (GSE-CI) reported a significant drop of $25 \%$ in trading firms' performance. Ghana is weak in the fight of attaining developed economy even though reports from the World Bank shows the country is recovering from the drastic GDP fall of 3.4 percent with 55 billion US dollars from 2014 to 2015 .

In this regard, the delisting and suspension of firms on the GSE could result from many underlining technical factors. Researchers have studied firms' performance on the GSE by investigating factors that could impact performance level by looking into liquidity, working capital, capital structure, and corporate social responsibilities (Baafi et al., 2020; Li et al., 2019; Amponsah-Kwatiah \& Asiamah, 2020; Asiedu et al., 2020). In light of the above, this study seeks to examine conditions that could influence financial health by examining earnings management of non-financial companies on the GSE. The empirical findings on earnings management in the extent of such engagements have questioned how beneficial or detrimental income manipulation is to GSE firms' performance. The research is undoubtedly focused on knowledge generation, awareness creation in the Ghanaian setting, and its control.

The empirical findings set to inform the market securities on what is transpiring in the firms listed on the GSE to tackle earning management practices. The accounting fraternity also stands to gain useful information and ideas to formulate appropriate policies to streamline the accounting profession to promote financial performance. In addition, the intuitive thoughts on earnings managements to impact firm performance adversely is eliminated or reduced. Therefore, we advise managers not to pursue opportunistic behavior but pay greater attention to managing earnings' efficient capabilities.

\section{LITERATURE REVIEW AND HYPOTHESIS DEVELOPMENT Earnings Management}

Earnings management is altering a company's earnings to make financial statements appear better than the real reports. The practice is commonly used by managers to accomplish their corporate goals. (Cohen et al., 2010; Roychowdhury, 2006; Zang, 2012). Arguments have thrown light on the purpose of the practice as opportunistic or efficient on managers. Negatively, the strategy is viewed as management manipulating profits to benefit or demonstrate that the business is performing well to the detriment of shareholders and other stakeholders. (Ronen \& Yaari, 2008).

Cohen et al., (2007) defines the practice as the right granted to a company's managers to choose accounting processes and practices to accomplish specific goals. This definition implies that managers choose accounting processes and practices that benefit them because such methods allow them to present a desirable company performance. Linck (2013) also argues that earnings management is rather efficient and not limited to the implicit opportunistic nature.

Earnings management is a tool for companies to achieve a predetermined goal. A preference for more stable earnings can meet this goal; in this case, management is said to be performing income smoothing. Smoothing income could, opportunistically, signal lower risk and increase the stock value of firms. Earnings management may also be motivated by other factors, such as exceeding analyst expectations by advocating for a leveled accounting ratio to prevent debt issues and the pressure to maintain earnings growth. Nasiri \& Ramakrishnan (2020) attributed earnings management to a flawed governance system when investigations were made in Malaysian firms. Evidence of analogous situation are found in other 
emerging economies (Matteo and Francesco, 2018; Blkasem \& Mansor, 2019; Khuong et al. 2019).

\section{Firm Performance}

In the corporate world, financial performance is an index in determining the health of an organization. Various financial performance measurements are measured in various ways, such as shareholders' wealth maximization, profitability, and components of financial statements including sales, total assets, and equity. A firm's profit is usually measured using profitability ratios such as ROA, ROE, and profit margin. Investors tend to invest in companies that have been profitable in previous years. Achieving good financial results is a must; otherwise, the organization's financial standing will worry creditors and shareholders, inhibit its capacity to finance project required and may even place its very life at risk. Shareholders' wealth maximization is also an essential aspect of a company. Under shareholders' wealth maximization, there are two aspects to be considered that is; Economic Value Added and Market Value Added. Under economic value-added, these are the benefits that a company enjoys during its operations. In market value-added, there is market share. Market share's significance must be noted because it enables one to realize organization strength, whether they are leaders or minor players, and whether the organization is still holding, gaining, or losing its target market share. Market ratios measure how the firm performs in terms of dividends, share earnings, and price-earnings (Li et al., 2019). Companies are usually in competition to ensure that they enjoy a large share of the market as this improves their profitability.

\section{Accrual Earnings Management and Firm Performance}

The accrual concept is a crucial accounting principle that requires companies to acknowledge income and expense items when the benefit is obtained rather than when the cash is paid or received. This is one of the GAAP that managers take advantage of to increase or decrease performance (Dechow \& Skinner, 2000). Accrual control does not include changing the company's underlying activities; instead, it involves selecting accounting methods to reflect various activities carried out by the company. Accrual accounting, therefore, gives managers significant power to determine profits at different periods. Thus, managers have authority over the cost item recognition time frame. They can also identify profits, such as earlier revenue recognition through credit sales, to manipulate profits to suit the manager's needs. (Teoh et al, 1998).
Many studies have reported the existence of accrual earnings management and the diverse association with company performance. Arguments have been raised that the magnitude of earnings management practices may impact firm performance. Also, studies found that performance can also influence the shift in earning management level since lower or higher earnings can motivate firms to manage earnings. Firms facing economic problems are likely to alter earnings upward, unlike firms with extreme performance that engage in downward earnings reporting by creating a big bath. Prior research has shown that earnings management practice and found lower-performing firms participate in incomeincreasing management strategies. Linck et al. 2013 claimed financially constrained firms desire manipulate income to boost their chances of realizing a possible future investment return. Suprianto \& Setiawan, (2020) as well provided evidence that accrual earnings management is rather efficient than opportunistic in Indonesian firms. Evidence of poor performance due to accrual earnings management was also supported by Dakhlallh, 2020.

As already indicated, Ghana is a developing country with high political instability and a weak regulatory system. We anticipate that weak rules and scrutiny would impact corporate performance. As a result, we propose the following hypotheses:

Hla: The level of accrual earnings management improves firms' $R O A$.

$H 2 b$ : The level of accrual earnings management improves firms' $R O E$.

\section{Real Earnings Management and Firm Performance}

Real earnings management is the process of changing company operating activities to increase current period profits. In firm operations, real activity management may take several forms, such as expanding production/overproduction to reduce sales expenses or slashing certain desirable costs, including $\mathrm{R} \& \mathrm{D}$, in order to increase current profits. According to Schipper (1989), real earnings management happens when a company's administrators deliberately modify the timing or arrangement of activities, acquisitions, or financial transfers to manipulate the published figures in the financial statements.

Agency theory holds that the association between earnings management and firm performance depends on managers' opportunistic perspective. Information asymmetry likewise also leaves investors with less information necessary required to make beneficial decisions. Accordingly, managers use earnings to signal good future performance by making 
short-term sacrifices that may benefit them. The notion that the benefits may offset associated costs and eventually improve firm performance.

Prior research findings contradict one another regarding the positive and negative implications of EM and corporate performance. However, real activitiesbased earnings management is either beneficial or harmful to performance when it is found to be effective or opportunistic, respectively. Supported by empirical evidence, real earnings management's future consequences in the seasoned equity offerings (SEO) periods were negatively associated with return on assets with high-leveled real earnings management (Cohen \& Zarowin, 2010). Similarly, (Jiang et al., 2018; Khuong et al., 2019) showed companies use a real earnings management approach to accelerate current profit and efficiency. They found their results consistent with the study of Gunny (2010). In contrast, Wang and Zheng (2019) found real earnings to be negatively associated with firm performance. Similar negative relationship results were found in the works of (Leggett et al, 2016; Francis et al, 2016).

There is a possibility that investors or analysts expect profitable firms to show good performance. As a result, such firms will likely practice upward earnings management to meet analysts' and investors' expectations. As indicated earlier, developing countries have high tendency of engaging in income management due to weak regulations and political instability. The following hypotheses are therefore stated:

H2a: The level of real earnings management results in higher firms' $R O A$.

$H 2 b$ : The level of real earnings management results in higher firms' $R O E$.

\section{METHODOLOGY}

This study seeks to find the relationship between earnings management and firm performance of listed firms on the Ghana Stock Exchange. It is a quantitative research and hence, a purposive sampling approach was employed to meet the standard analytical process. Data gathered for this study is secondary in nature from annual financial reports of non-financial firms from the year 2008 to 2019. A panel data analysis was adopted to achieve the objectives and purpose of this study.

Table 1: Sample Selection Process

\begin{tabular}{ll}
\hline Description & No. of Firms \\
\hline Firms listed on the GSE & 43 \\
Less: & 11 \\
Firms not listed on the GSE mainboard & 14 \\
Firms operating in the financial industry & 3 \\
Firms without complete annual reports from 2008 & 1
\end{tabular}

\section{Study Model and Variables}

Primarily focusing on the study's purpose, financial reporting is considered resourceful and must be dealt with integrity due to the direct and significant influence earnings management could have on it (Healy \& Wahlen, 1999).

In light of past research, this examination adopts discretionary accruals in estimating accrual earnings management and anomalous degrees of operations cash flow as proportions of real earnings. The above two proxies constitute a complete measurement of earnings management and how they influence ROA and ROE. Accordingly, and addition to the below model variables are firm size, leverage and liquidity as control variables:

$$
\begin{array}{ll}
\mathrm{ROA} & =\beta_{0}+\beta_{1} \mathrm{DA}+\beta_{2} \mathrm{RMCFO}+\beta_{3} \mathrm{FS}+\beta_{4} L E V+\beta_{5} L Q+\varepsilon \\
\mathrm{ROE} & =\beta_{0}+\beta_{1} \mathrm{DA}+\beta_{2} \mathrm{RMCFO}+\beta_{3} \mathrm{FS}+\beta_{4} L E V+\beta_{5} L Q+\varepsilon
\end{array}
$$

where ROA is a measurement of firm performance, $\mathrm{ROE}$ is the measurement of firm performance; $\beta=$ beta coefficient; $\mathrm{DA}=$ discretionary accruals; $\mathrm{RMCFO}=$ abnormal cash flow for operation; FS $=$ firm size, $\mathrm{LEV}=$ leverage; $\mathrm{LQ}=$ liquidity; $\varepsilon=$ error term 


\section{Measuring Firm Performance}

Return on assets (ROA) is used as the proxy for firm performance. The efficiency of a company in generating income through assets is shown by ROA. It is estimated by dividing net income by total assets. Secondly, return on equity (ROE) is used as proxy for firm performance in model II. ROE demonstrates how beneficial an organization is by expressing the measure of benefits an organization gets with its shareholders' investments. ROE is measured by dividing net income by shareholders equity (Ding et al., 2018; Liu, 2018; Petitjean, 2019).

\section{Measuring Accruals Earnings Management}

In this study, we use the modified Jones model, as proposed by Dechow et al (1995), to identify earnings management by calculating discretionary accruals as a proxy for accrual earnings management. Although the modified Jones model is the most effective at identifying accrual earnings, Islam et al. (2011) and Yoon et al. (2006) argue it is ineffective for firms in Asia. Despite the downside of the modified Jones model's effective evaluation, it can better detect discretionary accruals among the established models. Below is the Modified Jones Model for the estimation of discretionary accruals;

$$
\frac{T A C_{i, t}}{T A_{i, t-1}}=\alpha_{1} \frac{1}{T A_{i, t-1}}+\alpha_{2} \frac{\left(\Delta R E V_{i, t}-\Delta R E C_{i, t}\right)}{T A_{i, t-1}}+\alpha_{3} \frac{P P E_{i, t}}{T A_{i, t-1}}+\varepsilon_{t}
$$

The residuals from equation are considered to be the discretionary level of accruals. The higher the residuals, the greater the number of discretionary accruals (DA).

Where $\mathrm{TAC}=$ Total accruals in year $\mathrm{t}$ computed as difference between net income and cash flow from operating activities. TAC $=$ NET INCOME $-\mathrm{CFO}$; $\mathrm{TA}_{\mathrm{i}, \mathrm{t}-\mathrm{l}}=$ Total assets at the beginning of year $\mathrm{t} ; \Delta \mathrm{REV}_{\mathrm{i}, \mathrm{t}}$ $=$ Change in revenue in firm $\mathrm{i}$ in year $\mathrm{t} ; \Delta \mathrm{REV}_{\mathrm{i}, \mathrm{t}}=$ Change in receivables in firm i in year $t ; P_{P E i}, t=$ Gross property, plant and equipment in firm $\mathrm{i}$ in year $\mathrm{t} ; \varepsilon_{t}=$ Error term

\section{Measuring Real Earnings Management}

Real activity-based earnings management is estimated Abnormal Cash Flow from operations. The method was developed by Roychowdhury (2006) and have extensively been used in prior studies (Cohen, et al., 2007; Farooqi et al., 2014; Kim \& Park, 2014; Tian et al., 2018; Dakhlallh, 2020). The model was developed on the assumption that managers boost earnings by changing sales strategies through the discount provision and flexible deals with debtors. The intention is temporarily to record high sales resulting in an increased inflow of cash from operations. We consider this activity as abnormal cash flow from operations in our study.

Following Roychowdhury (2006), The residuals of these models are regarded as the abnormal values. Abnormal cash flow from operations is estimated with the model below;

$$
\frac{C F O_{t}}{T A_{t-1}}=\alpha_{0}+\alpha_{1} \frac{1}{T A_{t-1}}+\beta_{1} \frac{S_{t}}{T A_{t-1}}+\beta_{2} \frac{\Delta S_{t}}{T A_{t-1}}+\varepsilon_{t}
$$

The residuals from equation (4) are used to calculate the abnormal cash flow level from operation RMCFO. The higher the residuals, the greater the amount of abnormal cash flow from operations and the greater the increase in reported profits due to increased sales.

Where $C F O_{t}=$ Cash flow from operation firm i in year $\mathrm{t}$; $R M C F O=$ Abnormal cash flow from operation; $T A_{t-1}=$ Total assets of firm i in year t; $S_{t}=$ Total sales of firm i in year $\mathrm{t} ; \Delta S_{t}=$ Changes in sales of firm $\mathrm{i}$ in year $\mathrm{t} ; \Delta S_{t-1}=$ Changes in firm sales $\mathrm{i}$ in year $\mathrm{t} ; \varepsilon_{t}=$ Error.

\section{RESULTS \\ Descriptive Statistics}

Table 2 shows the descriptive statistics for the study variables in our model. It shows the variables' mean, standard deviation, minimum and maximum values. Our first measure of firm performance, ROA, as a dependent variable, has a mean of 0.0759 and a standard deviation of 0.3135 , indicating that listed companies have a lower average return on assets when the minimum and maximum values are -0.520 and 3.722 , respectively. Our second performance indicator, ROE, differs from ROA by a much smaller mean of 0.011 , showing that returns on shareholders' equity are low. DA has a mean value of -0.001 and a standard deviation of 0.229 , reflecting that firms are lowering discretionary accruals. 
Table 2: Descriptive Statistics

\begin{tabular}{cccccc}
\hline Variable & Obs & Mean & Std. Dev. & Min & Max \\
\hline ROA & 168 & 0.075942 & 0.313525 & -0.520074 & 3.722273 \\
ROE & 168 & -0.011180 & 1.166446 & -12.89505 & 4.107666 \\
DA & 154 & -0.001854 & 0.229935 & -1.303519 & 1.457256 \\
RMCFO & 154 & $-1.95 \mathrm{E}-09$ & 0.219037 & -1.104284 & 1.409172 \\
FS & 168 & 5.914720 & 1.011179 & 4.340405 & 8.125427 \\
LEV & 168 & 0.08767 & 0.129403 & 0 & 0.744999 \\
LQ & 168 & 1.919206 & 2.561166 & 0.118255 & 17.66800 \\
\hline
\end{tabular}

The fact that the mean of RMCFO is -1.95 suggests that companies participate in downward earnings management through lenient credits sales and price discounts. Firm size turns out with a mean of 5.94 compared to the other control variables, leverage and liquidity, with mean values of 0.08 and 1.98 , respectively

\section{Unit Root and Co-integration Test}

To avoid spurious regression results of our analysis, we perform the Augmented Dicker-Fuller unit root test to ensure our study variables are all stationary. The ADF unit root test's null hypothesis assumes that the variables have a unit root. Hence, p-value $<0.05$ permits us to reject the null hypothesis. Table 3 illustrates the presence of non-stationary variables at the log level based on the p-values, but all variables resulted as stationary at First Difference.

Table 3: Augmented Dicker-Fuller Fisher Unit Root Test

\begin{tabular}{cccc|ccc}
\hline \multicolumn{3}{c}{ Augmented Dicker-Fuller Fisher Unit Root Test } \\
\hline \multicolumn{3}{c}{ Log Level } & \multicolumn{3}{c}{ First Difference } \\
\hline Variables & $\begin{array}{c}\text { Statistics } \\
\text { Chi-square }\end{array}$ & Prob.** & Status & $\begin{array}{c}\text { Statistics } \\
\text { Chi-square }\end{array}$ & Prob.** & Status \\
& 83.1895 & 0.0000 & Stationary & 101.093 & 0.0000 & Stationary \\
ROA & 58.1869 & 0.0007 & Stationary & 96.3102 & 0.0000 & Stationary \\
ROE & 98.6607 & 0.0000 & Stationary & 138.913 & 0.0000 & Stationary \\
DA & 102.588 & 0.0000 & Stationary & 142.628 & 0.0000 & Stationary \\
RMCFO & 11.6513 & 0.9972 & Non-Stationary & 78.8750 & 0.0000 & Stationary \\
FS & 39.8134 & 0.0407 & Stationary & 76.4017 & 0.0000 & Stationary \\
LEV & 44.9463 & 0.0223 & Stationary & 109.048 & 0.0000 & Stationary \\
LQ & \multicolumn{7}{c}{}
\end{tabular}

\section{Cointegration Test}

Table 4 presents the cointegration test based on Kao Residual Cointegration. The purpose of the test is to establish if there is a correlation between several time series. The results in Table 4 permit us to reject the null hypothesis of no cointegration among the variables. Notably, the p-value is less than 5\%. Accordingly, the empirical discoveries accept that the examination factors are cointegrated.

Table 4: Kao Residual Cointegration Test

\begin{tabular}{lll}
\hline \hline & t-Statistic & Prob. \\
\cline { 2 - 3 } ADF & -8.802513 & 0.0000 \\
\hline \hline Residual variance & 0.006679 & \\
HAC variance & 0.004239 & \\
\hline \hline
\end{tabular}




\section{Granger Causality Test}

The Causality test in panel data allows the presence of a causal relationship between two variables to be determined. Beforehand, the possible cause of the absence of cointegration may be present amongst the study variables without them causing changes to each other. Affirming the stationarity status of time-series, and evidence of cointegration among the variables, we believe there can be a long run interaction among them.
Hence, there is a need to evaluate the causality between the variables. Granger stands to specify the adequacy of variable relationships amongst them. That is, accounting for heterogeneity across cross-section units. Per the Pairwise Granger causality test rule, the null hypothesis asserts no causal relationship between two variables. A p-value of less than 0.05 specifies the rejection of the null hypothesis.

Table 5: Pairwise Granger Causality Test

\begin{tabular}{lcccl}
\hline Null Hypothesis: & Obs & F-Statistic & Prob. & Inference \\
\hline DA does not Granger Cause ROA & 126 & 2.91278 & 0.0581 & Rejected \\
ROA does not Granger Cause DA & & 0.29409 & 0.7457 & Not rejected \\
& & & & \\
\hline RMCFO does not Granger Cause ROA & 126 & 4.05823 & 0.0197 & Rejected \\
ROA does not Granger Cause RMCFO & & 1.12190 & 0.3290 & Not rejected \\
& 126 & & & \\
\hline DA does not Granger Cause ROE & & 0.97387 & 0.3806 & Not rejected \\
ROE does not Granger Cause DA & 126 & 6.31871 & 0.0025 & Rejected \\
& & & & \\
\hline RMCFO does not Granger Cause ROE & & 0.35110 & 0.2162 & Not rejected \\
ROE does not Granger Cause RMCFO & & & 0.7190 & Not rejected \\
& & & \\
\hline
\end{tabular}

According to the findings in Table 5, the Eviews output from the Pairwise Granger causality test indicates that $p$-values of $<0.05$ in reference to the null hypothesis of the test call for the no rejection. However, results indicate that discretionary accruals (DA) Granger causes return on assets (ROA). Thus, there is a unidirectional causality among them. Specifically, historical discretionary accruals can predict the future return on assets. On the contrary, past ROA cannot make future predictions of DA. From Table 5, we find similar unidirectional causality among, Abnormal cash from operations (RMFCFO) and return on assets (ROA); and Return on Equity (ROE) and Discretionary accruals (DA).

\section{Selection of Panel Data Analysis Model}

This section introduces the statistical findings after accounting for all variables in the research models to determine whether earnings management affects company performance. The hypothesis developed for this study was tested to ensure validity. To detect the endogeneity problem, we used the Hausman test to determine whether the random effect or fixed effect is suitable.
The Hausman test is conducted based on the following hypothesis;

Ho: P-value $>0.05$, the Random effect model is appropriate for the study.

Ha: $\quad P$-value $<0.05$, the Fixed effect model is appropriate for the study.

Results of the Hausman test for the ROA model are reported in Table 6. Based on the Hausman statistics $(\mathrm{p}=0.0005)$, we are permitted to reject the null hypothesis of the random-effect of the p-value $(>0.05)$ for our ROA model. The Hausman statistics direct us to reject the null hypothesis. We then find the fixed-effect model the most suitable for ROA model $(\mathrm{P}=0.0000)$.

Table 7 reports the Hausman test for the ROE model. The p-value (0.2853) does not permit us to reject the null hypothesis. Hence, the Random effect model is appropriate for the ROE model.

\section{Hypothesis Testing and Results}

The fixed effect ROA model results in Table 6 shows the independent variables (DA, RMCFO) explain $80 \%$ of the dependent ROA. Thus, the total contribution of $20 \%$ dependent variable factors was not captured by the independent variables 
Table 6: ROA Fixed Effect Results for Model I

\begin{tabular}{llll}
\hline \hline Variable & Coefficient & t-Statistic & Prob. \\
\hline \hline DA & $0.624^{* * *}$ & 16.99007 & 0.0000 \\
RMCFO & $0.547^{* * *}$ & 13.44868 & 0.0000 \\
FS & $-0.100^{* * *}$ & -5.100214 & 0.0000 \\
LEV & 0.05511 & 0.791385 & 0.4301 \\
LQ & -0.00204 & -0.724081 & 0.4703 \\
C & $0.652^{* * *}$ & 5.476096 & 0.0000 \\
\hline \hline & & & \\
R-squared & 0.800860 & Durbin-Watson stat & 2.087779 \\
Adjusted R-squared & 0.774307 & Hausman & \\
F-statistic & 30.16185 & & \\
Prob(F-statistic) & 0.000000 & & \\
\hline \hline Source: Eviews; * Significant at 10\%; ** Significant at 5\%; *** Significant at 1\% &
\end{tabular}

Table 7: ROE Random Effect for Model II

\begin{tabular}{llll}
\hline \hline Variable & Coefficient & t-Statistic & Prob. \\
\hline \hline DA & $\mathbf{2 . 3 2 5 * * *}$ & 4.04362 & 0.0001 \\
RMCFO & $\mathbf{1 . 9 1 9 * * *}$ & 3.18528 & 0.0018 \\
FS & -0.07994 & -0.86566 & 0.3881 \\
LEV & 0.25886 & 0.32669 & 0.7444 \\
LQ & 0.02318 & 0.57276 & 0.5677 \\
C & 0.37004 & 0.64904 & 0.5173 \\
\hline \hline R-squared & 0.111779 & Durbin-Watson stat & 1.956508 \\
Adjusted R-squared & 0.081772 & Hausman & 0.2853 \\
F-statistic & 3.725044 & & \\
Prob(F-statistic) & 0.003321 & & \\
\hline \hline
\end{tabular}

Source: Eviews; * Significant at 10\%; ** Significant at 5\%; *** Significant at 1\%

The findings show a significant positive relationship between DA and ROA $(0.624, \mathrm{t}=16.99)$. The outcome explicitly shows that increasing earnings control by discretionary accruals results in a 0.624 improvement in company's ROA. The results conform to our hypothesis, meaning that firms enhance performance through upward accrual earnings management. Considering real earnings management metrics, results came out with significant positive coefficients except for RMPROD resulting in an insignificant relationship. (RMCFO 0.547, $\mathrm{t}=13.44$ ). This indicates that applying real earnings through salesbased manipulations would increase ROA.

Table 6 reports a negative coefficient for FS ($0.100, t=-5.100)$ for our control variables; thus, a percentage in total assets leads to a fall of -0.090 change in ROA, usually less expected. It could be argued that firm size establishing a negative link with
ROA could result from a firm's inability to fully utilize the total assets held to earned an efficient return on the assets. LEV appears to be insignificantly positive to ROA $(0.055, t=0.791)$, different from an insignificant negative result of LQ $(-0.002, t=-0.724)$.

In terms of the model II, the random effect ROE model findings are shown in Table 7 from the ROE model. The results are analogous to the above ROA model results in terms of DA, with a positive significant coefficient $(2.325, \mathrm{t}=4.043)$. This shows the extent of earnings through discretionary accruals will result in a 2.325 upward return on firm equity. Furthermore, we discover that RMCFO, as an independent variable and a proxy for real earnings management, has a significant positive relationship with $\operatorname{ROE}(1.919, \mathrm{t}=3.185)$. 
For the control variables, we find that the size of the company (FS) is negative. Leverage (LEV) and liquidity (LQ) were positively insignificant to return on equity (ROE) with $(-0.079, \mathrm{t}=-0.865 ; 0.258, \mathrm{t}=0.326$; $0.023, \mathrm{t}=0.567)$ respectively.

According to the random-effect model findings in Table 7, the independent factors (DA and RMCFO) describe $11 \%$ of the dependent ROE. As a result, the total contribution of $89 \%$ of dependent variable factors was not captured.

\section{DISCUSSIONS}

From the test results, we found a positive significant relationship between accrual earnings and return on assets. Similar outcome was found between real earnings management and return on assets. This signposts that the alteration of company activities and income has a direct impact of on financial performance.

This study was to examine the relationship between profit management and organizational performance. We find that earnings control affects ROA and ROE through the accrual income management methodology for the Ghana study of listed firms. Despite numerous studies and findings, intuitive thinking on profit management which affects company operations, is still growing. More so, sense has been derived from the results of this study that earnings management practices can influence firms' performance in a way, especially on the signal theory's account.

Although a positive interaction between accrual earnings and real earnimgs results could be explained by the fact that firm success is affected by workers' compensation, anything else that could lead managers to risk their compensation prospects might lead to higher profit management (Hessayr \& Saihi, 2015). Our findings are in accordance with the accrual models that conclude that $\mathrm{H} 2 \mathrm{a}$ and $\mathrm{H} 2 \mathrm{~b}$ are valid. The results reflect the work of Mostafa (2020), who found that Egyptian firms had positive links between discretionary accruals and company performance and the work of Linck et al (2013). However, the report's findings do not conform to the conclusions of Ardekani et al., (2012) and Okafor (2018).

The examination of real activities-based earnings management on firm performance (ROA and ROE) resulted in a significant positive relationship. Our findings demonstrate a positive relationship between abnormal cash flow from operations and firm performance. Abnormal cash flow from operations turned out to be positively significant, signifying firms enhance performance through real earnings management and accrual management compared. Therefore, Hypotheses $3 \mathrm{a}$ and $3 \mathrm{~b}$ are supported by our findings even though one metric of real activity-based earnings management failed to support the hypotheses. We find this significant positive relationship to support the work of Zamri et al. (2013). Our findings also support previous works (Tian et al., 2018; Dakhlallh, 2020; Khuong et al., 2019).

\section{CONCLUSION}

This study investigates the relationship between earnings management and firm performance in Ghana. We hypothesize that managers deviate from normal reporting standards by meeting their desired targets through management earnings practices. We adopted a panel of 14 non-financial listed companies on the GSE over the period from 2008 to 2019. Considering our preference for interpretation of results, our primary regression model assessment uses the models of fixed effect and random effect. Base on the empirical findings, we draw the following conclusions;

First, despite the existing accounting principles and regulations, managers deviate from the normal level of operations and reporting to manipulate earnings to some extent. We also find that the manipulation methods are complementary; thus, managers use accrual earnings and real earnings strategies to meet their goals. In a practical sense, managers, through lenient credits and discounted sales, increase sales volume within that period of temporal sales strategy, contributing to upward earnings. Second, cash flow results from operations and discretionary accruals appear to be effective. Albeit not in line with actual economic circumstances, it does not reveal opportunistic conduct. We find that the desire of management to increase income positively contributed to financial performance.

Also, we reach the signal theory with many predispositions of efficient or informational concept in the sense that managers take advantage of this incomeincreasing method to signal future firm value to the market. Contrary, the same edifying idea can be put up by camouflaging unproductive investments to mislead investors with inaccurate reports.

We recommend this study to managers based on the outcome of this study which unveils the underlying future predicaments of the earnings management practice. Thus, it must be noted that companies under such practice must consider the positive aspect of earnings management termed as the information signal approach where necessary, to prevent excess application and abuse of the flexibility of GAAP. Directors, senior executives, and the public are urged to pay attention to the latest development policies. Decisions should be coordinated with information dissemination in financial reports. Additionally, it is incumbent on the accounting community to also 
enforce policies and sanction any fiscal impropriety. We strongly recommend that regulators and facilitators put in place policies demanding that transponder financial reports. prior to investing, they should conduct an in-depth analysis.

Finally, we recommend future studies to use larger study population other than just listed companies and also consider other performance measures like Tobin's Q, firm growth and others. Other earnings management detection models like Modified Kaznik model should be considered.

\section{REFERENCES}

1. Amponsah-Kwatiah, K., \& Asiamah, M. (2020). Working capital management and profitability of listed manufacturing firms in Ghana. International Journal of Productivity and Performance Management, ahead-of-print(ahead-of-print). https://doi.org/10.1108/ijppm-02-2020-0043

2. Ardekani, A., Younesi, N., \& Hashemijoo, M. (2012). Acquisition, Earnings Management and Firm's Performance: Evidence from Malaysia. Journal of Business Studies Quarterly, 4(1), 91-110

3. Asiedu, M. A., Adegbedzi, D. K., Oduro, R., \& Iddrisu, S. (2020). Working Capital Management Effect on Return on Equity- Evidence from Listed Manufacturing Firms on Ghana Stock Exchange (GSE). International Journal of Finance and Accounting, $5(1)$, 47. https://doi.org/10.47604/ijfa.1125

4. Baafi, J. A., Duodu, J. K., Sarkodie, E. E., \& Boachie, W. K. (2020). Examining the Economic Interaction between Liquidity and Firms' Financial Performance: Evidence from the Ghana Stock Exchange. Journal of Economics, Management and Trade, 34-46. https://doi.org/10.9734/jemt/2020/v26i1030296

5. Blkasem, E \& Mansor, N. (2019). Earnings Management in Developed and Developing Countries: A Review of Recent Literature. American Based Research Journal. 8(1) 2304-7151

6. Chairunesia, W., Bintara, R., Molina, \& Subiyanto, B. (2020). Effect of Business Strategy and Profit Management of Company Performance (Case Study on Manufacturing Companies in the Consumer Goods Industry Sector on the Indonesia Stock Exchange 2013-2016). EPRA International Journal of Multidisciplinary Research (IJMR), 13-22. https://doi.org/10.36713/epra3889

7. Cohen, D. A., \& Zarowin, P. (2010). Accrual-based and real earnings management activities around seasoned equity offerings. Journal of Accounting and Economics, 50(1), 2-19. https://doi.org/10.1016/j.jacceco.2010.01.002

8. Cohen, D. A., Dey, A., \& Lys, T. Z. (2007). Real and Accrual-Based Earnings Management in the Pre- and Post-Sarbanes Oxley Periods. SSRN Electronic Journal. https://doi.org/10.2139/ssrn.813088

9. Dakhlallh, M. M. (2020). Accrual-based Earnings Management, Real Earnings Management and Firm Performance: Evidence from Public Shareholders Listed Firms on Jordanian's Stock Market. Journal of Advanced Research in Dynamical and Control Systems, 12(1), 16-27. https://doi.org/10.5373/jardcs/v12i1/20201004

10. Darmawan, I. P. E., T, S., \& Mardiati, E. (2019). Accrual Earnings Management and Real Earnings Management: Increase or Destroy Firm Value? International Journal of Multicultural and Multireligious Understanding, $6(2), \quad 8$. https://doi.org/10.18415/ijmmu.v6i2.551

11. Dechow, P. M. and Skinner, D. J. (2000), "Earnings Management: Reconciling the Views of Accounting Academics, Practitioners, and Regulators", Accounting Horizons, vol. 14, no. 2, pp. 235-250

12. Dechow, P.M., R.G. Sloan \& A.P. Sweeney. (1995). Detecting Earnings Management, The Accounting Review, 70, 193-225

13. Ding, R., Li, J., \& Wu, Z. (2018). Government affiliation, real earnings management, and firm performance: The case of privately held firms. Journal of Business Research, 83, 138-150. https://doi.org/10.1016/j.jbusres.2017.10.011

14. Farooqi, J., Harris, O., \& Ngo, T. (2014). Corporate diversification, real activities manipulation, and firm value. Journal of Multinational Financial Management, 27, 130-151. https://doi.org/10.1016/j.mulfin.2014.06.010

15. Francis, B., Hasan, I., \& Li, L. (2014). Abnormal real operations, real earnings management, and subsequent crashes in stock prices. Review of Quantitative Finance and Accounting, 46(2), 217260. https://doi.org/10.1007/s11156-014-0468-y

16. GDP growth (annual \%) - Ghana| Data. (n.d.). Data.worldbank.org. Retrieved March 9, 2021, from

https://data.worldbank.org/indicator/NY.GDP.MKT P.KD.ZG? end $=2019$ \&locations $=G H \&$ start $=2008$ \&view $=$ chart

17. Gunny, K. A. (2010). The Relation Between Earnings Management Using Real Activities Manipulation and Future Performance: Evidence from Meeting Earnings Benchmarks. Contemporary Accounting Research, 27(3), 855-888. https://doi.org/10.1111/j.1911-3846.2010.01029.x

18. Healy, P. M., \& Wahlen, J. M. (1999). A Review of the Earnings Management Literature and its Implications for Standard Setting. SSRN Electronic Journal. https://doi.org/10.2139/ssrn.156445

19. Hessayri, M., \& Saihi, M. (2015). Monitoring earnings management in emerging markets. Journal of Economic and Administrative Sciences, 31(2), 86-108. https://doi.org/10.1108/jeas-112014-0029

20. Islam, Md. A., Ali, R., \& Ahmad, Z. (2011). Is Modified Jones Model Effective in Detecting 
Earnings Management? Evidence from A Developing Economy. International Journal of Economics and Finance, 3(2). https://doi.org/10.5539/ijef.v3n2p116

21. Jiang, H., Habib, A., \& Wang, S. (2018). Real Earnings Management, Institutional Environment, and Future Operating Performance: An International Study. The International Journal of Accounting, 53(1), 33-53. https://doi.org/10.1016/j.intacc.2018.02.004

22. Khuong, N. V., Nguyen, T. H. \& Phung, A. T. (2019). The Relationship between Real Earnings Management and Firm Performance: The Case of Energy Firms in Vietnam, International Journal of Energy Economics and Policy, Econjournals, vol. 9(2), pages $307-314$

23. Kim, Y., \& Park, M. S. (2014). Real Activities Manipulation and Auditors' Client-Retention Decisions. The Accounting Review, 89(1), 367-401. https://doi.org/10.2308/accr-50586

24. Leggett, D., Parsons, L. M., \& Reitenga, A. L. (2009). Real Earnings Management and Subsequent Operating Performance*. SSRN Electronic

Journal. https://doi.org/10.2139/ssrn.1466411

25. Li, K., Musah, M., Kong, Y., Adjei Mensah, I., Antwi, S. K., Bawuah, J., Donkor, M., Coffie, C. P. K., \& Andrew Osei, A. (2019). Liquidity and Firms' Financial Performance Nexus: Panel Evidence from Non-Financial Firms Listed on the Ghana Stock Exchange. SAGE Open, 10(3), 215824402095036. https://doi.org/10.1177/2158244020950363

26. Linck, J. S., Netter, J., \& Shu, T. (2013). Can Managers Use Discretionary Accruals to Ease Financial Constraints? Evidence from Discretionary Accruals Prior to Investment. The Accounting Review, 88(6), 2117-2143. doi:10.2308/accr-50537

27. Liu, Z. (2019). Unraveling the Complex Relationship between Environmental and Financial Performance: A Multilevel Longitudinal Analysis. International Journal of Production Economics. doi:10.1016/j.ijp.2019.07.005

28. Mellado, C., \& Saona, P. (2019). Real earnings management and corporate governance: A Study of Latin America. Economic Research-Ekonomska Istraživanja, $\quad 33(1), \quad$ 2229-2268. https://doi.org/10.1080/1331677x.2019.1691930

29. Mostafa, W. (2020). Operating performance and manipulation of accruals. Management Science Letters, 985-994. https://doi.org/10.5267/j.msl.2019.11.012

30. Nasiri, M., \& Ramakrishnan, S. (2020). Earnings Management, Corporate Governance and Corporate Performance among Malaysian Listed Companies. Journal of Environmental Treatment Techniques. 8(3), 1124-1131

31. Okafor, T., Ezeagba, C., \& C.I., O. (2018). Effect of Earnings Management on Performance of
Corporate Organisation In Nigeria. International Journal of Business Management and Economic

32. Petitjean, M. (2019). Eco-friendly policies and financial performance: was the Financial Crisis a Game Changer for Large US Companies? Energy Economics, $\quad 80, \quad 502-511$. https://doi.org/10.1016/j.eneco.2019.01.028

33. Ronen, F. I. \& Yaari, P. (2008). The Effects of Earnings Per Share, Dividend Per Share and Price to Earnings Ratio on Share Prices: The Case of Firms Listed at New York Securities Exchange. Innovative Research and Studies, 2(9), 30-44

34. Roychowdhury, S. (2006). Earnings management through real activities manipulation, Journal of Accounting and Economics 42(3), 335-370

35. Schipper, K. (1989) 'Commentary on earnings management', Accounting Horizons, Vol. 3, No. 4,pp.91-102

36. Suprianto, E., \& Setiawan, D. (2020). Accrual earning management and future performance: Evidence from family firm in Indonesia. Jurnal Akuntansi \& Auditing Indonesia, 24(1), 33-42. https://doi.org/10.20885/jaai.vol24.iss 1.art4

37. Teoh, Siew Hong, T.J. Wong, and Gita Rao, 1998, Are accruals during an initial public offering opportunistic? Review of Accounting Studies 3, $175-208$

38. Tian, X., Yang, T., \& Yu, T. R. (2018). Real earnings management in family firms: evidence from Chinese listed firms. International Journal of Revenue Management, 10(2), 77. https://doi.org/10.1504/ijrm.2018.091814

39. Yoon, S. S., \& Miller, G. A. (2002). Cash from operations and earnings management in Korea. The International Journal of Accounting, 37(4), 395-412. https://doi.org/10.1016/s00207063(02)00193-0

40. Zamri, N., Rahman, R. A., \& Isa, N. S. M. (2013). The Impact of Leverage on Real Earnings Management. Procedia Economics and Finance, 7, 86-95. https://doi.org/10.1016/s22125671(13)00222-0

41. Zang, A. Y. (2012). Evidence on the Trade-Off between Real Activities Manipulation and AccrualBased Earnings Management. The Accounting Review, 87(2), 675-703. https://doi.org/10.2308/accr-10196 